\title{
DISCUTINDO O CONCEITO DE INOVAÇÃO CURRICULAR NA FORMAÇÃO DOS PROFISSIONAIS DE SAÚDE: O LONGO CAMINHO PARA AS TRANSFORMAÇÕES NO ENSINO MÉDICO
}

\author{
DISCUSSING THE CONCEPT OF CURRICULAR INNOVATION IN THE TRAINING \\ OF HEALTH PROFESSIONALS:THE LONG ROAD TOWARDS THE CHANGES \\ IN MEDICAL EDUCATION
}

Victoria Maria Brant Ribeiro ${ }^{1}$

Resumo Este artigo é produto do trabalho de investigação sobre iniciativas de inovação curricular, com base nas Diretrizes Curriculares Nacionais (DCN), em escolas médicas públicas de Minas Gerais e do Rio de Janeiro, uma delas vinculada ao Programa de Incentivo às Mudanças Curriculares no Ensino Médico (Promed). Ressaltam-se três questões na análise do material empírico, uma de natureza metodológica, outra de natureza política e uma última de natureza histórico-cultural e científica, correspondendo ao que se apresenta neste artigo: a discussão sobre o conceito de inovação; os desdobramentos da análise das falas que possibilitaram mapear a situação atual da formação do estudante de medicina nas instituições selecionadas, traçando um quadro da visão e das concepções pedagógicas de educação médica e do nível de conhecimento das DCN, sob o ponto de vista de professores e estudantes; e as expectativas dos estudantes quanto à sua formação relacionada ao mundo do trabalho. A metodologia adotada segue os princípios da pesquisa qualitativa, razão pela qual a técnica de entrevista utilizada é o grupo focal, que oferece material empírico, analisado teoricamente, e que retorna aos atores (professores, gestores e estudantes) em atividades práticas com vista às inovações curriculares. ${ }^{2}$

Palavras-chave inovação curricular; ensino médico; educação e saúde.
Abstract This article is a product of research work about initiatives of curricular innovation based on the National Curricular Guidelines (DCN) and carried out in State medical schools in the states of Minas Gerais and Rio de Janeiro. One of these schools is connected with the Programme to Promote Curricular Changes in Medical Education (Promed). In the analysis of the empirical material, three questions - respectively of a methodological, political and historiccultural and scientific nature - correspond to what we present in this article, namely: the discussion about the innovation concept; the various developments of the analysis of the speeches, that enable us to draw a profile of the current situation of the medical education in the selected institutions, and thus to have a clear picture of the pedagogical perspectives and conceptions in medical education and estimate the knowledge levels of the DCN, from the teachers' and pupils' points of view; and the students' expectations with regard to the training and its connection with the world of work. The methodology selected follows the principles of qualitative research and, for this reason, we used the focal group interview technique. This technique gives us the empirical material that, analyzed theoretically, is presented once more to the actors (teachers, administrators, and students) inserted in practical activities oriented to the curricular innovations.

Key words curricular innovation; medical education; education and health. 


\section{O anúncio}

Parafraseando o que se comenta sobre a justiça, as mudanças no ensino superior tardam, mas não falham, sobretudo após a homologação das Diretrizes Curriculares Nacionais (DCN), a partir de 2001, com base nas quais as escolas serão avaliadas, fato determinante para que ocorram inovações nos currículos.

As primeiras profissões que tiveram suas diretrizes regulamentadas pelo Conselho Nacional de Educação (CNE/CES), por meio de Resolução3 ${ }^{3}$, foram as do campo da saúde, em especial as do ensino médico, em conjunto com a nutrição e a enfermagem. Um ano depois (2002), os ministérios da Saúde e da Educação uniram-se para implantar o Programa de Incentivo às Mudanças Curriculares no Ensino Médico (Promed), oferecendo recursos para as escolas que se dispusessem a inovar seus currículos, apresentando propostas viáveis de integração escola-comunidade-serviços, com ênfase na atenção primária.

Este artigo apresenta o processo de investigação sobre iniciativas de inovação curricular, em decorrência das DCN, com base em resultados de investigação realizada em escolas médicas públicas de Minas Gerais e do Rio de Janeiro, uma vinculada ao Promed e outra sem auxílio deste programa. Os resultados obtidos, os quais instrumentalizam este estudo, são também utilizados em oficinas com professores e estudantes, ocasião em que se discutem, produzem e avaliam novas estratégias pedagógicas para o ensino médico.

O projeto desenvolve-se, portanto, com os objetivos de acompanhar as inovações relativas à compreensão dos professores sobre novos métodos e novas práticas de ensino como formas de benefícios sociais e as inovações relativas à adesão deles a novos processos de ensinagem ${ }^{4}$, com base nas competências definidas nas diretrizes curriculares; produzir conhecimento sobre resultados dos processos de inovação em andamento; acompanhar programas e projetos pela construção, em processo, de instrumentos e/ou mecanismos que avaliem avanços e obstáculos para implementar inovações curriculares; discutir com os sujeitos da pesquisa possibilidades e limites da implantação de inovações curriculares, contribuindo para a reflexão sobre a prática e a concepção pedagógicas adotadas e sobre as expectativas de formação dos estudantes.

Foram identificadas, de imediato, três questões a serem enfrentadas pela equipe: uma, de natureza metodológica, levanta a discussão sobre os conceitos de inovação e de competência como referência de análise das falas de professores e estudantes obtidas por meio de grupos focais 5 ; outra, de natureza política, trata das questões de resistência e de adesão às inovações, associadas ao afastamento entre a academia e a comunidade; e uma última, de natureza histórico-cultural e científica, lida com a tradição do ensino médico no qual está consolidada a conhecida dicotomia teoria-prática. 
Diante da amplitude dessas questões, optou-se por desenvolver neste artigo: a discussão sobre o conceito de inovação; os desdobramentos da análise das falas que possibilitaram mapear a situação atual da formação do aluno de medicina nessas instituições públicas selecionadas, do ponto de vista do desenvolvimento curricular vigente, traçando um quadro das concepções e inovações pedagógicas, da visão de educação médica e do nível de conhecimento das DCN, dos pontos de vista de professores e estudantes destas instituições; e as expectativas dos estudantes quanto à sua formação, relacionada ao mundo do trabalho.

A metodologia adotada segue os princípios da pesquisa qualitativa ao considerar "sujeito de estudo: gente, em determinada condição social, pertencente a determinado grupo social ou classe com suas crenças, valores e significados" (Minayo, 1998, p. 22), razão pela qual a técnica de entrevista utilizada é o grupo focal, forma de livre expressão sobre problemas, experiências, negociação de conflitos e outros dados relativos aos objetivos do projeto.

\section{Mudança, reforma, inovação, transformação: o que está valendo}

A nova configuração do mundo do trabalho, em especial no campo da saúde, vem exigindo um novo perfil profissional mais sintonizado com competências que ultrapassam a excelência técnica (sem dúvida fundamental) e incluem as dimensões socioeconômicas e culturais para enfrentar os problemas de saúde da população, nas esferas individual e coletiva, e não apenas na hospitalar. Das escolas, esperam-se iniciativas que articulem formação e questões de saúde do Sistema Único de Saúde (SUS), com ênfase especial no nível de atenção primária e, portanto, a adoção de um modelo curricular diametralmente oposto ao tradicional chavão: primeiro se aprende para depois trabalhar.

Ora, se alterações há de haver, algo novo deverá ser incluído para que não se permaneça no nível de mudança ou de reforma, uma prática com a qual convivemos desde o $2^{\circ}$ Plano de Ensino do Brasil, a Ratio, inaugurado e implementado em 1599 pela Companhia de Jesus, que tratava da educação da elite colonial com elementos da cultura européia, perseguia uma orientação universalista, sem preocupação com o regional, afastada do espírito científico e tinha como principal método de ensino a cópia dos clássicos. Ainda nesta mesma perspectiva, em 1750, tivemos a Reforma Pombalina, por meio da qual mudaram os conteúdos retóricos e livrescos nas escolas em uma tentativa de recuperar os anos perdidos em relação à moderna ciência européia - uma nítida intenção de modernizar a elite brasileira — sem, entretanto, mudarem os métodos.

Esse pano de fundo introduz a discussão dos significados de inovação e de mudança que, para não cair no atual 'conforto teórico' de se afirmar que 
são conceitos polissêmicos, coloca autores dos mais diferentes matizes ideológicos em posições absolutamente contrárias (ou não!) ao se referirem a eles.

No conjunto dos conceitos hoje considerados estruturantes da formação e da prática em saúde ('competência', 'integralidade', 'educação permanente' e outras categorias teóricas que nomeiam a maior parte da literatura sobre o tema), concordamos em parte com Sebarroja (2002, p. 11) para quem inovação significa "um conjunto de idéias, processos e estratégias, mais ou menos sistematizados, mediante os quais trata-se de introduzir e provocar mudanças nas práticas educativas vigentes".

Para o autor, o objetivo da inovação é alterar a realidade por meio de mudanças em concepções e atitudes — nível subjetivo — no ato educativo; portanto, a intenção situa-se em nível micro das relações intra-escolares. Ainda para o autor, a inovação diferencia-se das reformas que afetam o sistema educativo como um todo e da modernização da escola pela introdução de novas tecnologias ou novas formas de interação com a comunidade que não realizem mudanças efetivas na concepção e na prática pedagógicas, reproduzindo antigos esquemas em novos cenários. Aí reside nossa diferença com a definição-chave de Sebarroja e seus desdobramentos, na medida em que, ao se incluírem idéias, processos e estratégias sistematizados nas práticas educativas, estamos introduzindo algo novo e não apenas mudando as coisas de lugar. Mesmo que as estruturas socioeconômica, cultural e política não sejam contaminadas, o novo na prática educativa produz efeito, no mínimo, de desconfiança, o que prenuncia ou a busca interessada ou a resistência a esse novo. Em ambos os casos, as relações intra-escolares são abaladas. A inovação está, então, para além das mudanças, o que se pode inferir da fala de um professor entrevistado da Escola Promed6.

\footnotetext{
“Então, não basta exclusivamente a inovação tecnológica, da tecnologia pura, mas seria inovação também aquilo que pudesse capacitar o formando médico a ter mais competência técnica pra lidar com a pessoa e o seu processo de adoecimento, ou seja, em uma inovação teria que caber: um aumento da capacidade intelectual, com atitude comportamental do formando e habilidade de comunicação, de relacionamento interpessoal, habilidade de compreensão no processo de adoecimento e da inter-relação de variáveis dessas ordens e acho que da promoção de saúde no sentido mais amplo, mais próximo da qualidade de vida. Acho que em inovação curricular entrariam essas questões" (professor Promed).
}

Sobre as resistências à mudança, Sebarroja (2002) cita sete pecados capitais que podem comprometer a inovação: a inércia institucional, o individualismo, o corporativismo, a formação docente, a falta de um clima de confiança e de consenso, a intensificação do trabalho docente, o controle burocrático e a falta de apoio da administração educativa, nenhum deles por nós desconheci- 
do. Afinal, “o espaço físico, a forma de organização de turmas, a sala de aula, o quadro negro, a separação dos horários, os exercícios, os estímulos, o currículo escolar, o credenciamento etc. estão presentes desde pelo menos há seiscentos anos com características muito semelhantes" (Nunes, 2001, p. 3).

De outro lado, Sebarroja sugere que sejam aprofundados dez 'mandamentos' da inovação educativa, dos quais quatro nos interessam mais de perto: deve resultar em processo tão simples e tão complexo quanto aquilo que os professores fazem e dizem; deve ser acompanhada de assessoria, reflexão, investigação e avaliação; não deve ser morta pelas discussões infindáveis que a nada conduzem e por atitudes pessimistas e lamentosas que substituem a crítica transformadora; e deve assumir que a dúvida, a incerteza, o conflito e o desacordo são fontes preciosas de aprendizagem em qualquer processo de inovação.

Diante destes mandamentos, pode-se imaginar o conjunto de singularidades do perfil docente inovador. Somente como uma provocação, extraímos do texto do autor as seguintes: tomar partido frente a qualquer ordem de desigualdades; acompanhar o estudante pelo continente do saber; comprometer-se com as transformações das práticas educativas; converter as dificuldades em possibilidades — uma concepção freireana; guardar coerência entre o que diz e o que faz; reivindicar a utopia.

Ora, esse conjunto de singularidades nada mais é do que um rompimento com a ordem estabelecida, com riscos muito bem apresentados por Feurewerker:

\footnotetext{
“Concepções pedagógicas mais modernas, sobretudo quando envolvem o estabelecimento de relações mais democráticas entre professores e estudantes, provocam reações violentas nas escolas médicas. Talvez por isso mesmo seja muito forte o impacto produzido pela ruptura com as concepções tradicionais e pela adoção de metodologias ativas de ensino-aprendizagem, que mudam os papéis de alunos e professores" (Feuerwerker, 2002, p. 28).
}

Conhecido filósofo da educação e respeitado por sua ousadia em 1980, na $1^{\text {a }}$ Conferência Brasileira de Educação, ao anunciar a ruptura paradigmática do tecnicismo com a teoria crítica dos conteúdos, Saviani (1980, p. 17), em estudo sobre filosofia da educação, afirma que a concepção humanista de homem - seja a tradicional ou a moderna — por considerá-lo constituído por uma essência imutável, não comporta o tema inovação, que "simplesmente não é considerada; e, se o é, ocupa, obviamente, um lugar secundário, periférico, acidental".

Da mesma forma, o autor refere-se à mudança que, nesta ótica, é considerada também acidental. Justifica essa premissa com base nos métodos tradicionais de educação, de orientação humanista, que não podem conceber 
qualquer alteração que se insurja contra os princípios humanistas. Decorre daí um primeiro critério traçado pelo autor para caracterizar a inovação: "inovador é o que se opõe a tradicional" (Saviani, 1980, p. 18).

Uma sutil diferença marca o conceito de inovação educacional nas concepções humanistas tradicional e moderna. Enquanto na tradicional o foco é o conhecimento, o intelecto e o educador, na moderna o foco está no educando, na vida, na atividade (ação), razão pela qual ao invés de "subordinar os meios (métodos) aos fins (o homem adulto, o domínio cognitivo cultural disponível), subordina os fins aos meios" (Saviani, 1980, p. 19). Por conseqüência, a inovação substitui a ordem lógica pela ordem psicológica, e nada se altera significativamente.

Avançando para a concepção analítica da filosofia da educação, cuja tarefa é analisar a lógica da linguagem educacional, e o que articula significado ao significante, Saviani afirma que inovação depende do contexto em que é utilizada; portanto, não há critérios pré-determinados para analisá-la.

Quanto à concepção dialética da filosofia da educação, "interessa-lhe o homem concreto, (...) como síntese de múltiplas determinações, (...) como o conjunto de relações sociais" (Saviani, 1980, p. 20). A realidade é compreendida em todo seu dinamismo, razão pela qual não é preciso

“negar o movimento para admitir o caráter essencial da realidade (concepção ‘humanista' tradicional) nem negar a essência para admitir o caráter dinâmico do real (concepção 'humanista' moderna). O dinamismo se explica pela interação do todo com as partes que o constituem e pela contraposição das partes entre si. Determinada formação social, mercê das contradições que lhe são inerentes, engendra sua própria negação no sentido de uma nova formação social" (Saviani, 1980, p. 20-21).

Assumimos, então, a concepção dialética que radicaliza o sentido de inovação, dando-lhe o significado de alterar as raízes, as bases. Segundo Saviani, esta é uma concepção revolucionária de inovação.

Uma síntese provisória nos permite esquematizar o seguinte: mudar significa alterar posições, quantidades; inovar significa introduzir algo novo que altera, de alguma forma, o antigo, abalando sua composição original, sem, contudo, alterá-lo estruturalmente.

A revisão de literatura realizada por Jorge (1996) confirma o conceito de inovação que assumimos para analisar o material de campo da pesquisa. Desde o Diccionário de las ciencias de la educación (1988), no qual se encontra definida como uma "ação permanentemente realizada mediante investigação, para buscar novas soluções aos problemas do âmbito educativo", passa por González e Muñoz (1987), que a compreendem como "mudanças mais concretas e em menor escala, com uma intervenção mais centrada na prática educativa que no sistema educativo", e por Huberman (1973), que a 
ela se refere, segundo a autora, como um "melhoramento possível de se medir, planejado, duradouro e com poucas possibilidades de acontecer com freqüência" (Jorge, 1996, p. 33). A própria autora concebe inovação como "uma série de mecanismos e processos mais ou menos deliberados e sistemáticos, por meio dos quais se tenta produzir e promover mudanças nas práticas educativas vigentes" (Jorge, 1996, p. 54). Para esse conceito, toma de empréstimo a Huberman (1973, p. 1) a idéia de que a inovação "parece oferecer uma alternativa real de mudanças em um contexto em que a história mostra não ter havido nunca uma ruptura radical entre o novo e o velho".

Ainda Jorge, em uma visão um tanto otimista, afirma que, conscientemente ou não, os professores estão sempre passando pela experiência da inovação, uma vez que, em decorrência de aspectos sociais, culturais e técnicos, surgem sempre novas idéias, que os levam, freqüentemente, a refletir sobre e criticar seu próprio fazer pedagógico, o que nos leva a pensar a transformação como resultado extremo do efetivo engajamento do professor em proposta contida na inovação.

Culminando a argumentação sobre o avanço do conceito de inovação sobre o de mudança, encontramos no debate de Cunha (2003) com renomados cientistas da educação o que a seguir se apresenta, pois reflete com nitidez o que compreendemos por inovação.

"As inovações que adivinhamos próximas se materializam pelo reconhecimento de formas alternativas de saberes e experiências, nas quais imbricam objetividade e subjetividade, senso comum e ciência, teoria e prática, cultura e natureza, anulando dicotomias e procurando gerar novos conhecimentos mediante novas práticas. Essas inovações, entendidas como ruptura paradigmática, exigem dos professores reconfiguração de saberes e favorecem o reconhecimento da necessidade de trabalhar no sentido de transformar, como refere Santos, a 'inquietude' em energia emancipatória (2002:346). Envolvem o reconhecimento da diferença e implicam, em grande medida, um trabalho que consiste, especialmente, em gerir relações sociais com seus alunos. Incentivar o processo de inovações é agir contra um modelo político que impõe, não raras vezes, a homogeneização como paradigma" (Cunha, 2003, p. 149).

Comentando a posição de Cunha, extraímos dos debatedores complementos e ajustes considerados essenciais para os nossos propósitos. Leite acrescenta:

“Os professores estão em silêncio, realizando práticas que estão 'às margens'. Essas práticas das margens seriam as inovações pedagógicas. (...) A meu ver, para a produção do novo importa a clareza com a qual atravessamos as fronteiras e se o fazemos junto com nossos alunos. Ao final, as inovações buscadas podem não ser 
(...) assim tão novas. Inovador terá sido caminhar fazendo o caminho. (...) É preciso clareza também para perceber que as inovações estão situadas na linha de tensão entre saberes e poderes. Na prática da sala de aula, da universidade, dentro do sistema de ensino tal qual como na sociedade, revelam-se poderes desiguais. E, a poderes desiguais correspondem saberes desiguais, perpetuando a escala da reprodução social com a qual todos nós podemos estar seriamente comprometidos" (Leite, apud Jorge, 2003, p. 152).

Balzan, mais crítico e menos otimista, inicia seu comentário reproduzindo trechos de Cunha para, em seguida, expor sua crítica.

\begin{abstract}
“Inovações [que] exigem dos professores uma reconfiguração de saberes e favorecem o reconhecimento da prática de trabalhar no sentido de transformar a inquietude em energia emancipatória (...) Inovações que implicam um trabalho que consiste, especialmente, em gerir relações sociais com seus alunos (...) Ensinar é fazer escolhas, constantemente, em plena interação com os alunos. A quem é endereçado este discurso? São raros os professores, do ensino fundamental ao superior, que estão inquietos, isto é, indignados com o quadro atual da educação brasileira, entusiasmados com os processos reconhecidamente inovadores e que geram bons resultados, preocupados com os rumos da escola pública, da universidade etc. Penso que há poucos saberes para serem reconfigurados, que grande parte dos docentes se aproxima mais do modelo ameba do que de um retrato vivo e colorido de pessoas preocupadas em gerir relações sociais com seus alunos, conscientes da necessidade de fazer escolhas" (Balzan, apud Jorge, 2003, p. 157).
\end{abstract}

Por fim, a quase poética réplica de Cunha.

“Viver a possibilidade é o nosso desafio. Inovações que incorporam as contradições, mas não navegam sem rumo. Na provisoriedade enxergam seu lume, acreditam na sua utopia. São exigentes enquanto esforço humano, pois se alicerçam em pilares da complexidade. Não abdicam do sonho, como argumenta Freire (1986), 'que é a possibilidade de ir além do amanhã sem ser ingenuamente idealista, numa relação dialética entre denunciar o presente e anunciar o futuro'" (Cunha, 2003, p. 158).

Em uma outra perspectiva, Almeida (1999), com base em Matus (1993) e Rovere (1993), situa a inovação como um dos níveis de aprofundamento dos processos de mudança. Indica a educação médica como o objeto-sujeito das mudanças, submetida a diferentes níveis de análise e/ou intervenção: inovação, reforma e transformação, nessa ordem de profundidade. Nesse sentido, a inovação assume um caráter diferente daquele conceito que vimos sustentando, na medida em que nada se altera por ser o nível mais 'sim- 
ples' da mudança: aquele que se situa no nível fenomênico (Ferreira, 1988), de trocas quantitativas (na carga horária, nos conteúdos, nos processos ou relações) sem qualquer alteração qualitativa.

Se, no entanto, considerarmos a própria etimologia da palavra inovação, verificamos que sua origem (innovatio, onis) significa novidade, algo novo; portanto, o processo de inovar significa introduzir algo novo que não apenas altera a quantidade, mas a qualidade, se pensarmos esta alteração em uma perspectiva dialética.

Continuando na sua mesma perspectiva, Almeida refere-se à educação médica ainda embrionária para que se possa sobre ela afirmar que esteja em um patamar de reforma, mas somente em nível de inovação, no sentido de que as mudanças que ocorrem - as inovações — são superficiais, "concentramse as atividades nos meios e nas relações técnicas entre os agentes de ensino e o processo de ensino. (...) as intervenções que se enquadram neste plano resultam em alterações isoladas de processos, ou de conteúdos ou de relações, com maior ênfase nas alterações de processos" (Almeida, 1999, p. 10).

Com base nesta discussão, reafirmamos nosso entendimento de inovação curricular: alterações que buscam construir novos processos de formação dos profissionais e novas relações com a estrutura socioeconômica envolvendo, nessas relações, outras, referentes aos conteúdos, processos e métodos de ensinagem. Inclui, portanto, alterações significativas no currículo que podem se tornar o embrião de transformações importantes na relação universidade-escola-comunidade.

Embora o conceito de competência tenha sido referencial para a investigação, priorizamos discutir inovação por três razões principais: a necessidade de clarear o conceito que sustentou o livre debate nos grupos focais com o objetivo de identificar o que, de fato, está ocorrendo no ensino médico das escolas investigadas e o papel do Promed após dois anos de implantação; os impedimentos para reformular o currículo, sabendo-se que ultrapassamos o limite do prazo para as escolas implantarem as DCN; a farta e competente literatura sobre o conceito de competência e a complexidade que ainda cerca essa discussão, o que poderia gerar um outro artigo. De qualquer forma, não podemos nos eximir de informar nosso entendimento do conceito, até porque foi o que balizou a leitura das falas dos sujeitos investigados.

Por competência, compreendemos a capacidade de os indivíduos mobilizarem suas potencialidades de forma integral, em contextos diversos; supõe o desenvolvimento de um conjunto de atributos que os habilitem a reconverter sua qualificação em outra, dependendo da demanda de novas funções, a conviver em grupo, sensível às diferenças, e a avaliar novas situações enfrentando-as com criatividade.

Em síntese, o que se procura sistematizar no material da investigação é o conjunto de concepções, abordagens, conflitos de idéias, argumentações, 
incertezas, silêncios e demais formas de expressão nas falas de professores e estudantes ao se pronunciarem sobre as possibilidades e os impedimentos para transformar o ensino médico, em especial relacionando-o com o SUS.

\section{Mobilização para discutir diretrizes curriculares nacionais no campo da saúde}

Nos últimos anos vem crescendo a visibilidade do trabalho que realizamos em relação às DCN no campo da saúde, de tal forma que outras áreas vêm nos procurando para assessorar suas reformas curriculares. Entre elas, curiosamente, estão a meteorologia, a biblioteconomia, a veterinária, a zootecnia e a ficologia, estas três últimas ligadas ao campo da saúde, mas não exata e diretamente tratando da saúde humana. Adotando os mesmos procedimentos metodológicos (grupos focais, definição de categorias teóricas e análise das falas) e com nossa participação direta e constante, em julho de 2003 foi aprovada em diversos colegiados do Centro de Ciências da Saúde da Universidade Federal do Rio de Janeiro (UFRJ) a versão final do Curso de Graduação em Saúde Coletiva, vinculado ao Núcleo de Estudos de Saúde Coletiva (Nesc).

Esta última conquista merece destaque, na medida em que a participação dos estudantes-bolsistas do projeto em tela - nos grupos focais realizados com grande parte do corpo docente do Nesc - e a coordenação do processo de seleção, análise e definição das competências do egresso deste curso foram decisivas para aprofundar os estudos sobre as DCN e os conceitos referenciais da pesquisa: inovação, competência e, em especial, currículo. A experiência nesses grupos focais e na análise das falas trouxe mais segurança para o trabalho com os professores e os estudantes das escolas investigadas.

Esse bosquejo sobre nosso trabalho pretende apontar a pertinência dos procedimentos metodológicos empreendidos e sua capacidade de mobilizar atores para refletirem sobre as inovações curriculares e sobre as possibilidades que atividades desta natureza - grupos focais nos quais se constroem conhecimentos e concepções em clima de liberdade da palavra - trazem como espaços dialógicos, aqueles que efetivamente acolhem os sujeitos que serão responsáveis pelas transformações.

Um ponto ficou bastante claro para nosso grupo: um processo de transformação curricular pode se prolongar por, no mínimo, uma geração de estudantes. Em outras palavras, o tempo de realização de transformações não é necessariamente ajustado a beneficiar os atores que as promovem. Essa dissonância requer compreender a dimensão social desses processos, para além das conjunturas de cada instituição, do tempo de gestão de equipes dirigentes, entre outros aspectos. Há, como observamos nas falas dos professores, mais suspeitas sobre a necessidade de processar alterações em conteú- 
dos, em métodos de ensinagem, em atividades práticas do que propriamente ousadia, capacidade estratégica de conduzir processos e ganhar condições políticas para realizá-las.

As falas obtidas nos grupos focais mostram, com clareza, que as escolas tentam inovar, mas esbarram nos mais diferentes obstáculos: ausência de formação pedagógica para os professores, pouca intimidade com a área das ciências sociais, forte resistência para romper modelos tradicionais de formação, receio de inserir os estudantes precocemente no campo de prática sem os conceitos das ciências básicas consolidados, dificuldade para integrar conhecimentos com outras áreas do saber, entre outros. Reduzidas essas resistências à sua dimensão técnica, apagam-se as verdadeiras possibilidades de transformação e enfrentamento das contradições que subjazem às resistências aludidas.

Algumas tentativas de inovação metodológica propostas pelo grupo de pesquisa nas oficinas foram muito bem aceitas e deixaram a expectativa de que, com assessoria permanente, podem ser postas em prática. Dois exemplos ilustram essa avaliação de resultados: a utilização do método de Aprendizagem Baseada em Problemas7 e a avaliação por meio de portfolio 8 . As duas experiências mostraram o quanto podem contribuir para formar profissionais com competência para enfrentar, de modo autônomo, situações inesperadas, caso típico daqueles que trabalham na área da saúde.

Em uma avaliação ainda parcial das atividades do projeto, podemos afirmar que os fatores positivos preponderaram sobre os negativos, mesmo considerando que neste período de vigência do projeto tivemos de lidar com problemas que extrapolaram nossa competência. São considerados positivos: o avanço na proposição de novos métodos de ensino e de avaliação em currículos por competências por meio das oficinas nas escolas investigadas e em outras para as quais somos chamados; a integração de alunos de graduação e pós-graduação em torno de temas comuns não só aos seus trabalhos monográficos quanto aos que dão suporte ao projeto; a retomada das discussões sobre o modelo vigente de formação do profissional da saúde, tomando por base o modelo que integra a universidade com os serviços de saúde e a comunidade; a experiência em novos cenários de aprendizagem com a participação em projetos do Ministério da Saúde, uma oportunidade de lidar com as novas estratégias das políticas públicas: educação permanente e gestão participativa; a constatação do potencial da técnica de grupos focais como forma de entrevista na qual a palavra é livre, sem coação, portanto uma possibilidade de desenvolver 'situações ideais de fala', na concepção habermasiana ${ }^{9}$.

Quanto aos fatores negativos, podemos atribuí-los às conhecidas dificuldades de reunir professores e estudantes de medicina, considerando que seu cotidiano de trabalho é pautado pelas incertezas e pelo horário integral 
que dedicam à escola. Em síntese, podemos apontar: greves e paralisações em universidades participantes adiando os encontros e reduzindo, em alguns grupos focais, o número ideal de estudantes e professores, o que levou a algumas perdas do ponto de vista da riqueza dos debates; mudanças administrativas (chefias, coordenações de cursos e reitorados) em escola participante que afetaram a seleção inicial firmada entre a equipe da pesquisa e os professores, gestores e estudantes das escolas investigadas, levando-nos a contatar outra que imediatamente nos acolheu.

Sem qualquer intenção de apelo, as obrigações burocráticas a que estão submetidas as universidades e seus pesquisadores têm sido um obstáculo desgastante que impede a criação de muitas inovações que poderiam contribuir mais para o avanço científico.

\section{A matéria investigada}

Os procedimentos metodológicos adotados, como foi anunciado, seguem os princípios da pesquisa qualitativa, lembrando que os sujeitos da pesquisa têm as suas complexidades, subjetividades, verdades, os seus silêncios, características que são levadas em conta neste tipo de estudo. Foram transcritas na íntegra as falas e fez-se sua classificação por núcleos de sentido que, segundo Minayo (1998), compõem uma comunicação cuja presença ou freqüência signifiquem alguma coisa para o objetivo analítico visado.

Os critérios de seleção dos participantes constituíram-se em um problema para a equipe, razão pela qual socializamos a decisão com as equipes pedagógica e de gestores das escolas. O grupo de estudantes foi constituído por representantes de todos os períodos (ou anos) e por representantes do Centro Acadêmico. Para a escolha dos professores adotou-se um critério inusitado: aqueles que, de fato, têm compromisso com a aprendizagem do estudante, compromisso este avaliado, principalmente, em termos de permanência na escola, atendimento constante aos estudantes, interesse pelas inovações curriculares e iniciativas voltadas para a atenção básica.

Dessa forma, as concepções e visão pedagógicas de educação médica, o nível de conhecimento das DCN sob os pontos de vista dos professores e estudantes destas instituições e as expectativas sobre a formação constituíram os núcleos de sentido que permitiram traçar um quadro para compreender o significado das inovações curriculares identificadas.

Um primeiro e flagrante resultado pode ser atribuído ao auxílio do Promed. A escola que recebe este auxílio, mesmo que tenha em sua história uma forte articulação com os serviços e a comunidade, promoveu uma série de melhorias e de avanços em diferentes setores. Passado o período entre o primeiro e o segundo grupo focal, a resposta à pergunta 'houve inovação 
curricular' foi positiva, tanto por parte dos estudantes quanto por parte dos professores. É claro que as vozes dissidentes fazem restrições, mas o cômputo geral, ao final das discussões, sinalizou benefícios de ordem física (melhoria das condições das salas de aula), tecnológica (acesso à internet por meio da criação do Laboratório de Informática), acadêmica (16 pequenos projetos de pesquisa realizados, tendo como critério o envolvimento de um professor, um estudante e um profissional dos serviços) e científica (participação crescente de grande contingente de estudantes e professores em congressos, com trabalhos aprovados, com financiamento possibilitado pelos recursos do Promed).

Esses resultados vêm mobilizando a comunidade acadêmica, com as exceções de sempre. Há, sem dúvida, um clima de proximidade entre os pares, de compromisso mais consciente com os trabalhos da escola. Este é o cenário que encontramos e que nos permitiu identificar mais do que as iniciativas de inovação, o terreno sobre o qual estas iniciativas ocorrem: é o que passamos a apresentar.

\section{Concepções pedagógicas de estudantes e professores sobre a educação médica}

Os estudantes da Escola Promed partem do princípio de que o vestibular, nos moldes atuais, seleciona os estudantes pelos conhecimentos gerais e não por especialidades. Contrariamente, segundo estudos realizados (Cabral e Brant, 2004), muitos candidatos escolhem suas especialidades antes mesmo do vestibular10, o que, segundo os autores, pode se constituir em um (des)caminho para a formação generalista, tal como esperam os estudantes desta escola: uma formação que se caracterize pelo "humanismo e seus desdobramentos, o acolhimento, o respeito àquela pessoa, o entendimento que aquela pessoa que está procurando tem sofrimento, desenvolver essas habilidades e também a crítica em relação à ciência, o que é pouco estimulado e trabalhado durante a formação" (estudante Promed). Ao mesmo tempo - a nosso ver significando um considerável grau de maturidade - esses mesmos estudantes reconhecem a importância da formação técnica e científica paralela à humanista, com a ressalva de que, seja qual for a organização curricular, um ponto deve ser respeitado: que o currículo seja construído democraticamente. O exemplo eles viveram na disciplina antropologia médica, criada em 2003, durante um seminário com participação de professores das áreas biomédicas e sociais, estudantes, gestores e pessoal dos serviços, inclusive os 'de ponta', como representantes das equipes do Programa de Saúde da Família (PSF) local.

Pode-se sintetizar a concepção pedagógica na educação médica, dos estudantes Promed, como a possibilidade de "desenvolver a competência de 
criar vínculo com paciente por meio da comunicação, da atenção às queixas e à família, da humanização no atendimento e no cuidado, abrangendo tanto o conhecimento técnico quanto a sensibilidade de perceber o paciente em todos os seus aspectos bio-psico-sócio-afetivos" (estudante Promed).

A crítica que esses estudantes fazem diz respeito ao curso fragmentado, às práticas que submetem seus desejos à vontade do professor, e admitem que a possibilidade de transformar passa pela provocação para "desestabilizar" o docente.

“Se essa mudança acontecer de fato, será mais por conta do aluno do que do professor, pois aí entra a questão da estabilidade. O professor está dando aquela aula há muito tempo e vai descobrir de repente que mudou tudo, que a avaliação que está dando é mal dada. Quando começamos a discutir essa questão com ele, começamos a tirar a estrutura de estabilidade" (estudante Promed).

Os estudantes da Escola N-Promed encontram oportunidade para discutir abordagens de ensino em poucas disciplinas. Citam a medicina integral, recentemente criada, como um espaço possível e passível de desenvolver outra visão do exercício médico de modo mais humanizado, mais integral, mais democrático, preocupado com a visão de integralidade no cuidado à saúde. Defendem a criação de 'áreas verdes' em que se promovam discussões sobre novas formas de organização do curso, experiências externas (quando são realizadas) e uma visão de saúde que desconstrua o modo tradicional de pensar a doença como foco do trabalho médico. "As pessoas ficam perguntando em que eu vou me formar. Eu digo: calma, primeiro quero me formar em medicina. Apesar de que acho que existe um problema no sétimo período, quando vamos fazer estágio e já vamos definindo a especialidade" (estudante Promed).

Quanto à concepção dos professores, tanto nos da Escola N-Promed quanto nos da Escola Promed, embora nestes últimos em menor escala, há nítida mistura do discurso novo com antigas práticas.

Parte daqueles da Escola N-Promed mantém o discurso da necessidade de educação continuada, fazem a defesa do modelo tradicional e a crítica a qualquer inovação, embora reconheçam a importância dos aspectos sociais na formação - que pode ser contemplada na disciplina Medicina Integral - e ainda guardem traços da concepção que compreende a clínica médica como hegemônica.

Dois aspectos dessa questão merecem comentários. Na visão mais atual do campo da educação médica, inovação implica rupturas nas práticas hegemônicas substituindo-as por outras mais ajustadas às estratégias de atenção primária que supõem: promoção da saúde e intersetorialidade, controle social e superação da dicotomia entre educação e trabalho. Outro aspecto é 
que os professores-médicos, em especial, desconhecem a linguagem das ciências da educação, pois foram formados (e muitos ainda o são!) por currículos de base tecnicista, cujo foco é o corpo humano e suas partes em funcionamento (ou não!), deixando de lado tudo o mais que compõe este corpo: suas subjetividades, sua inserção social, os determinantes socioeconômicos das suas queixas, seus contextos familiar, social e cultural, enfim tendo por objeto de estudo o 'homem-máquina' e não o homem integral. Decorre destes aspectos a dificuldade de compreender o significado de competência enquanto estratégia de mobilização de conhecimentos e capacidades diante de situações novas, e justifica-se a fala angustiada de um estudante:

“Aqui, temos um professor que fala que em algumas situações você tem que dar a sua porção médica. Mas você tem que dar a sua porção médica, menos a parte técnica e mais (e eu acredito nesse modelo de médico) a parte de médico. É interessante isso. Não que eu não acredite que o médico precise da parte técnica, mas é que eu acho que existe uma coisa muito forte além da ciência, a arte" (estudante Promed).

Em contrapartida, na fala de uma significativa parte dos professores N-Promed encontramos afirmativas como: a responsabilidade da escola médica pública é com a saúde pública; a formação deve ser voltada para a atenção básica; a abordagem pedagógica precisa integrar conhecimentos científicos à humanização no cuidado; os benefícios da inserção precoce e da busca ativa resultam em possíveis e favoráveis conseqüências na prática hospitalar; a educação médica precisa urgentemente voltar-se para o desenvolvimento da competência, de trabalhos em equipe (o que transforma o exercício da profissão, integra outras profissões na hora de decidir), de habilidades de busca da informação, de crítica ao que está disponível, de construção do conhecimento, do habitus da dúvida.

Há, entre eles, um certo lamento relativo à fragmentação entre pesquisa e produção de conhecimento (biologia), idéias (medicina social) e técnicas (especialidades clínicas) e os estudantes afirmam que a integração é possível se as áreas estiverem no mesmo espaço físico.

Parece desnecessário afirmar que a pulverização institucional (física e acadêmica), desde o tempo do governo militar, fortaleceu a já fragmentada organização curricular do ensino superior, distribuída em disciplinas, com currículo mínimo e carga horária determinados pelo Ministério da Educação, legitimando, no ensino médico, o modelo tradicional ainda hoje vigente em muitas escolas e que responde à quase centenária proposta de Abraham Flexner (1910). Este modelo, composto por um ciclo básico — das ciências biológicas - seguido do ciclo profissionalizante corresponde à idéia de que o estudante precisa primeiro aprender teoricamente o funcionamento do corpo humano para depois aplicar o método clínico nos pacientes. Os pro- 
blemas de saúde da realidade na qual atuará como profissional são, usualmente, reduzidos às patologias aprendidas durante o curso, em geral objeto de estudo de muitos professores. E esse parece ser um complicador na relação professor-estudante, na diferença de visão dos dois, o que aparece na fala do estudante:

\begin{abstract}
“Eu penso muito na diferença entre atender e acolher. Em 15 minutos dá até para atender, mas não se acolhe não, não se cria um vínculo com o paciente em 15 minutos; é uma coisa meio prejudicada. Sei que não dá, extrapola tudo, mas acho que você tem que aprender a estabelecer os vínculos agora, pois vai chegar um dia que você não vai poder devido à estrutura do sistema. Por isso, o generalista está muito além do conhecimento técnico. Só que acho que vamos nos frustrar muito se for apenas isso, senão a medicina nunca vai nos satisfazer, nunca vai nos completar, acho que essa coisa do médico não olhar no olho e tudo mais em grande parte é por causa disso" (estudante Promed).
\end{abstract}

\title{
Visão de educação médica
}

Para os estudantes da Escola Promed não se viabiliza um novo modelo docente porque falta articulação, falta diferenciar desejo de vontade, sobram desejos e faltam vontades. O desejo pressupõe ação e a vontade é sempre inerente à ação. Ficam claras as críticas de que o curso é fragmentado, de que o desejo do estudante se submete à vontade do docente e os estudantes têm plena consciência da necessidade de enfatizar e diversificar métodos de avaliar.

\footnotetext{
"Vocês que tratam desses assuntos de educação devem informar que a prova não é um bom instrumento de avaliação; até concordo, mas o seminário é a forma melhor" (estudante Promed).
}

“Não é questão de a gente não estar acostumado com essa forma de avaliação por seminário; é questão de os professores não terem preparado uma nova forma de avaliação. Sou uma pessoa que odeio fazer prova, mas pelo menos com a prova eu estudo alguma coisa, eu aprendo alguma coisa" (estudante Promed).

A flexibilização curricular proposta pelas DCN abre possibilidades para articular a teoria com a prática — o que é considerado científico e os problemas de saúde da população - por meio de projetos de extensão, inserção precoce dos estudantes na rede de serviços, criação de espaços para que os problemas vividos no cotidiano dos serviços sejam discutidos com base nos conhecimentos científicos essenciais da formação profissional. A dificuldade que encontram refere-se à forma de implantar essa flexibilização, o 
que demanda uma nova visão de planejamento e de formas de acompanhamento que, por sua vez, requerem transformação na maneira ver o mundo e de lidar com a saúde.

Os estudantes compreendem claramente este problema e, de uma forma meio pessimista, um deles desabafa reclamando espaços e tempo para que os professores reflitam e discutam entre si suas práticas.

\footnotetext{
“Estamos trocando o pneu do carro com ele andando. Não tem como parar a faculdade. Outra coisa é você trocar o pneu errado. Oxalá que todas as disciplinas tivessem sido construídas como a disciplina de Antropologia Médica. Foi feito um seminário com participação dos professores, dos estudantes e do pessoal dos serviços, e é aí que acho que entra o ponto mais importante: tanto currículo quanto disciplinas, seja em que formato for, devem ser construídos democraticamente" (estudante Promed).
}

\section{Nível de conhecimento das Diretrizes Curriculares Nacionais}

A discussão com professores da Escola Promed indicou claramente o envolvimento de um grupo significativo com os princípios das DCN. Contudo, não há consenso sobre o perfil do egresso tal como as DCN o apresentam, o que nos parece ser o mote das discussões a que assistimos, fundamentadas, argumentadas e conscientes. Justifica-se a polaridade pela longa experiência de alguns professores no ensino tradicional, embora a característica da instituição - projetos de extensão e inserção nos serviços lhes dê uma visão mais humanizada do ensino do que normalmente encontramos naqueles que se mantêm resistentes às mudanças.

O grupo de professores que empreende inovações mostra uma visão clara da 'virada' curricular a partir da vigência das DCN, e já apresenta resultados importantes, reconhecidos tanto por seus pares quanto pelos estudantes. Para eles, sem dúvida, o apoio do Promed facilitou e agilizou processos, uns idealizados sem possibilidade para execução, outros nascidos do bem-sucedido casamento entre DCN e Promed.

Terminalidade foi um dos principais pontos levantados nas discussões. A formação generalista é defendida como uma forma de fortalecer a terminalidade, embora seja consenso a necessidade dos especialistas por uma razão principal: há, ainda, uma cultura na qual os usuários do sistema de saúde 'confiam' naquele médico que, nas falas dos estudantes N-Promed, caracteriza-se como um "especialista no cotoquinho do cotoquinho".

Segundo os professores Promed, em tom de crítica, "uma dor no peito é motivo para procurar imediatamente um cardiologista". No entanto, fica clara a defesa da especialidade em nível de pós-graduação (residência, espe- 
cialização ou mestrado): “faculdade de graduação, na minha opinião, tem que ter uma terminalidade: formar esse indivíduo ético, formar esse indivíduo humano, com formação geral de conhecimentos, competências, habilidades, atitudes. Dali pra frente ele faz o que ele quiser" (professor Promed). Uma das falas é emblemática do nível de compreensão dos princípios das DCN: "acho que isso aumenta a responsabilidade social, pois se estabelecem estratégias de prevenção e promoção, uma coisa que é importantíssima dentro das competências definidas nas Diretrizes" (professor Promed).

Em paralelo, indicam a importância conferida pelas DCN à formação científica e ao enxugamento do currículo, desde que se construam, em parceria, modos ativos de aprendizagem de modo a integrar conteúdos que se relacionem em torno de questões da prática, o que consideram uma inovação.

“(...) inovam na responsabilidade do docente como gestor do conhecimento; racionalizam o conhecimento" (professor N-Promed).

“(...) a pediatria tem trabalhos extremamente ricos, a medicina integral também tem, só que são coisas pontuais, espalhadas, que talvez ninguém saiba o que acontece do outro lado. Talvez se tudo isso se somasse, se fosse feito de forma integrada, talvez o tempo necessário fosse menor, mas nós não temos essa integração, até por formação é uma tendência dessa prática, a nossa classe é uma classe ainda muito difícil de trabalhar coletivamente" (professor N-Promed).

Em um balanço geral sobre o nível de conhecimento das DCN, podemos afirmar que um grupo minoritário de professores N-Promed debruçou-se efetivamente sobre o texto, mas destacou pontos que talvez lhes digam respeito mais diretamente, como se pode identificar nas falas seguintes sobre as competências elencadas no texto oficial.

“O exemplo clássico que eu dou na integração disso é quando eu pego um paciente e o estudo geneticamente, descubro que ele tem uma alteração genética e que ele vai ter um carcinoma medular de tireóide, talvez. Existe uma possibilidade e você tem que tentar com ele uma possibilidade de tireoidectomia total profilática. Então, colocar as vantagens e desvantagens dos riscos da cirurgia, se ele deseja ou não deseja, como a família vai aceitar, abordagem (...) ele não está só (competência para lidar com os familiares, não é?) eu tenho que tratar o ser humano como um todo" (professor N-Promed).

“E é um cenário (antecipação do exercício médico) que ele vai estar em contato com muitos profissionais, que é uma coisa que as diretrizes curriculares exigem: a liderança do médico na equipe de saúde" (professor N-Promed). 
“Eu sei, eu não conheço essa técnica (PBL). Mas como partir da prática para a teoria, pegando toda teoria que eu acho que tem que ensinar? E será que a teoria que eu quero ensinar é a teoria certa? Será que eu não preciso mudar a teoria que eu preciso ensinar? Será que é possível, em seis anos, eu dar um X de teoria, se hoje a teoria é uma coisa inacreditável. Então, eu acho que alguma coisa tem que mudar, o que eu acho interessante nas diretrizes curriculares novas. Aliás, não sei se são as mais novas" (professor N-Promed).

"Só que quando veio o Promed falou-se assim: nada de hospital, agora só o primário e o secundário - como se isso fosse possível. Isso é impossível! O ensino completo não tem que ser hospitalofóbico. Eu acho que isso é uma bobagem. Como é que eu vou criar um médico que tem medo de entrar num hospital e ver um paciente?" (professor N-Promed).

Reunidas as falas, podemos confirmar que apesar de algumas interpretações apressadas das competências definidas nas DCN, um 'novo' foi incluído nas instituições formadoras, provocando reflexão sobre as práticas docentes, sobre o que é essencial para a formação atual do médico, sobre a viabilidade de promover inovações radicais e outras iniciativas que, de alguma forma, abalam as instituições.

Do ponto de vista dos estudantes N-Promed, há dúvidas quanto às competências relacionadas à educação permanente e se neste campo está incluída a pesquisa científica. A principal razão apontada refere-se à possibilidade que se abre para formar médicos só para a área de saúde no que diz respeito ao aspecto social, tirando o papel científico do médico e, em especial, a importância de sólida formação na área clínica: “entendi que as diretrizes estavam excluindo essa parte científica e com isso eu discordo muito; é preciso enfocar mais a parte clínica. Conheço vários médicos que se formaram e não foram clinicar, foram pesquisar e trabalham na Fiocruz" (estudante N-Promed).

Quanto ao momento de realizar a mudança - conseqüência das DCN os estudantes dividem-se entre a mudança gradual e a radical. A defesa de uma reforma gradativa tem por argumento que "não se deva apenas colocar disciplinas, mas também tirar, reanalisar e fazer uma mudança grande" (estudante N-Promed). Os que discordam da mudança em processo afirmam:

\footnotetext{
“Tem que ser um 'pacotão' mesmo, ou seja, começar em um ano e a partir de então ser diferente. É óbvio que existe todo um processo, mas durante os outros anos. Se ficarmos discutindo pedagogia e educação com professores e estudantes, apenas os alunos dos anos seguintes é que vão pegar essas reformas. E acho que tem que mudar tudo. Tem que pegar, como exemplo, medicina integral que tem ótimos professores agora. E aí, vamos para a clínica médica. É completamente
} 
diferente da medicina integral; eles têm visão completamente diferente das coisas" (estudante N-Promed).

Para um estudante, as diretrizes propõem uma estratégia de educação continuada. Nesse sentido, foi preciso explicar a diferença entre educação continuada e educação permanente e abordar sinteticamente aspectos das políticas públicas de saúde, incluindo a implantação dos Pólos de Educação Permanente, que serão nucleadores da formação do profissional de saúde, no Brasil inteiro. Neles, as instituições de ensino, os conselhos municipais e estaduais de saúde, os gestores, as secretarias de saúde, os trabalhadores da saúde, as organizações da sociedade ou comunitárias são parceiros em projetos ou programas que necessariamente incluirão estudantes e professores, pessoal dos serviços, gestores e a população local. Nosso propósito foi verificar se professores e estudantes conhecem o movimento e acompanham o que está acontecendo. Nos grupos focais, os professores falam sobre o assunto, mas os estudantes não se referem a ele. Abrimos exceção para aqueles que estão mais ligados ao movimento estudantil, o que se confirma na fala da presidente do Centro Acadêmico da Escola N-Promed.

“Só para explicar, sou a atual presidente do Centro Acadêmico e desde o segundo ano estão fazendo essa discussão. Foram para o Congresso da Abem, para o Cobrem, e estão nessa discussão junto com a comissão que está discutindo o pólo. Aqui temos um colega que faz parte do Colegiado de Graduação, instância em que se está discutindo o pólo" (estudante N-Promed).

Há de se destacar o nível de conhecimento das DCN por parte dos estudantes da Escola N-Promed pela forma como abordam determinados aspectos, com críticas propositivas e algumas concordâncias, revelando que houve entre eles discussão sobre o texto, embora afirmem que "para a maioria do pessoal da escola, não sei (...) Eu acho que existe uma grande desinformação".

“Na verdade até hoje nós não passamos por uma reforma curricular na faculdade. O que está acontecendo é a integração ou não de uma disciplina com outra, é a formulação de uma disciplina nova. Tirar eles não tiram nenhuma, infelizmente. Colocam-se disciplinas novas por causa das diretrizes curriculares. Em todas as reuniões do conselho departamental, todas as coisas vinham em relação às diretrizes curriculares; informática deixou de ser opcional e passou a ser obrigatória" (estudante N-Promed).

“As diretrizes curriculares colocam a importância da informática para procurar artigos. Quanto à inserção precoce, a forma que encontraram aqui foi a medicina integral 1, 2 e 3. Precisava haver maior integração entre o básico e o clínico? En- 
tão criaram o Curso de Extensão, que não é disciplina, é curso, é MBA - Mecanismos Básicos do Adoecimento" (estudante N-Promed).

“Se você quer aumentar o internato para dois anos, porque quer ter mais tempo para passar nos ambulatórios e fazer mais alguma coisa, então você tem que mudar os primeiros quatro anos da faculdade. Se você quer colocar o estudante no posto de saúde desde o primeiro período, você vai ter que mudar alguma coisa no primeiro ano, que tem uma das maiores cargas horárias da faculdade. Então, tem que mudar a essência para formar um médico, porque o médico que se forma hoje não é como as DCN estão indicando" (estudante N-Promed).

“O pouco que lemos das diretrizes é que tem um 'pacote' básico comum do médico. A especialidade, seja ela clínica ou laboratorial ou sei lá o quê, ela tem que ser feita após os $\mathrm{X}$ anos. Então, se eu vou para o laboratório, vou ser médico de família ou vou ser superespecialista em joelho direito é uma opção que tenho após seis anos. Ninguém está descartando; achamos que é muito importante ter especialista. Tem um pacote básico, ou seja, o médico tem uma função social que é muito importante; ele vai se tornar médico depois de seis anos de curso - algumas coisas ele vai ter que saber como fazer - e isso é responsabilidade social" (estudante N-Promed).

"Acho que, junto com a reforma, tem que estar reformando o pensamento da universidade; isso tem que ser um projeto claro dentro da universidade, que eu não vejo" (estudante N-Promed).

“Há falta de discussão complexa e crítica acerca das diretrizes curriculares. Nós estamos no nosso mundinho falando as coisas, acho que liderança é importante; esse é um exemplo — obviamente que não é isso — de qual médico nós queremos formar? O início de tudo é ter uma discussão que seja realmente global para responder a essa pergunta. Tudo bem, nós temos as diretrizes curriculares, vamos ver de que maneira queremos ou podemos nos adaptar a isso; nossa instituição talvez não se adapte às diretrizes. Não é receber como apenas um pacote. Vamos discutir. Não sei se há uma disposição geral para discutir isso" (estudante N-Promed).

"E hoje começou de novo a questão do médico clínico-generalista que vê a pessoa como um todo. É não simplesmente estar dando o tratamento curativo, mas, sim, o cuidado. Agora está na moda a questão da humanização. Tem muito professor que dá a aula toda e depois diz para não esquecer a condição biopsicossocial do paciente. É, não sabe nem o que é isso, mas como está na moda" (estudante N-Promed).

“Na aula de semiologia clínica o professor chega e fica assim: como eu vou agir? A atitude dele sempre foi 'o que você tem? Tem isso, isso e isso, então é fígado'. O impacto social é muito mais na questão do cuidado, na questão da epidemiolo- 
gia e tudo mais. Mas ainda o perfil maior é de especialistas. Se você for perguntar na minha turma, a maioria já entrou na faculdade querendo fazer alguma coisa" (estudante N-Promed).

"A respeito da Medicina Integral como disciplina/espaço para alavancar as DCN, tem uma coisa boa e uma ruim. A coisa ruim é que ela acaba se tornando um pouco paliativa e ficam coisas pontuais e no fundo não chegamos no cerne da questão, que é aquilo que nós estamos querendo formar. E parece que já estamos conseguindo formar, com a Medicina Integral, os médicos de acordo com as diretrizes" (estudante N-Promed).

Quanto à Escola Promed - com tradição em programas na comunidade e maior aproximação entre estudantes e professores - , ela participou, desde o início, nas discussões sobre as DCN em nível nacional. Uma significativa parte dos estudantes, capitaneada pelo Centro Acadêmico, fez um estudo pormenorizado do texto final e se mostrou capaz de avaliar os efeitos do enxugamento curricular proposto pelas DCN. Ao mesmo tempo, foram capazes de compreender a amplitude das diretrizes pelo seu caráter de orientação em lugar de determinar o 'currículo mínimo' que até então vigorava e, ao analisarem o perfil do egresso proposto, revelaram os problemas atuais da formação. "Essa discussão está muito em voga agora, coisa que não existia, está fermentando, tomou-se como discurso aqui do professor, algumas disciplinas com propostas que tendem a adequar a formação mais próxima das diretrizes"' (estudante Promed).

A aprovação pelo Conselho Nacional de Educação das diretrizes curriculares para os cursos de medicina resultou da mobilização de diversos atores, em todo território nacional, com iniciativas, projetos, encontros e congressos promovidos nas e pelas instituições de ensino superior e associações representativas das categorias envolvidas, destacando-se, nesse movimento, o papel da Rede Unida com a experiência de implantação do Programa UNI (Uma Nova Iniciativa na Educação dos Profissionais de Saúde: União com a Comunidade) em escolas brasileiras de medicina e enfermagem. Essa experiência desenvolve nas escolas uma nova organização curricular, com base na relação com os serviços, práticas pedagógicas que articulam diferentes especialidades da área da saúde, procurando atingir resultados que integrem a comunidade acadêmica e demais segmentos envolvidos na formação profissional.

Essa referência é importante para que se possa compreender os diferentes níveis de entendimento das DCN por parte dos estudantes: um mais abrangente, outro mais pontual.

"Eu concordo com a avaliação que foi feita das disciplinas e que não dava para começar a reforma em 2002. Mas a comissão de reforma funciona desde 2000, en- 
tão não começou do nada. Concordo com vocês sobre os problemas dessas disciplinas, houve intensas discussões com envolvimento de alguns dos professores, obviamente, com participação dos alunos (embora muito aquém do que nós gostaríamos), mas não foi do nada. É importante nós entendermos tudo isso como uma reforma lenta: havia o coordenador da reforma curricular e um professor de cada departamento da universidade que dá aula para aluno da medicina, ou seja, todos os departamentos do CCS com exceção da Fisioterapia, todos os departamentos do ICB com exceção da Botânica e da Zoologia, com os quais não temos aula, e mais representação discente" (estudante Promed).

“Essa é a questão: diferenciar o que é problema da reforma, e o que é problema da nossa estrutura universitária, da nossa estrutura acadêmica e de professores. Nós tínhamos Anatomia que antes valia 14 créditos. Quero dizer, os 14 créditos não eram bem utilizados, então reduz-se o número de créditos para bem aproveitá-los, mas também não é para reduzir de 14 para dois e transformar Anatomia em um campo de concentração. É diferenciar o que é para reforma e o que é para a estrutura. Na Anatomia nós saímos sabendo bem, na Fisiologia geralmente saímos sabendo nada, e isso eu não acho que seja problema da reforma e sim do planejamento curricular" (estudante Promed).

\section{Expectativas dos estudantes em relação à formação}

O grau de conhecimento das DCN está diretamente relacionado às expectativas de formação dos estudantes. Há um componente novo nas escolas, há uma 'conversa' sobre a Reforma Sanitária, o atendimento de qualidade no SUS, a aproximação dos profissionais de saúde com a comunidade e os estudantes que, de modo geral, buscam inteirar-se do assunto, na medida em que são o foco dessas conversas.

O baixo grau de conhecimento das DCN por parte dos professores leva às mais diversas interpretações, refletindo-se nos estudantes sob a forma de dúvidas que têm sido objeto de discussão no Centro Acadêmico e em reuniões de representantes de turma. Os grupos focais muitas vezes se ocuparam de abrir espaço para explicações inevitáveis.

Uma das interpretações que merece aprofundamento diz respeito à educação permanente e sua 'concorrente' educação continuada. O diálogo a seguir, na Escola N-Promed, mostra a incerteza resultante de informações deslocadas e, ao mesmo tempo, a clareza dos estudantes sobre a formação que desejam.

estudante N-Promed - Eu tenho uma dúvida quanto às competências relacionadas à educação permanente. Isso inclui o desenvolvimento de pesquisa científica? 


\begin{abstract}
coordenadora - Claro, isso não é descartado em momento algum.
estudante N-Promed - Isso que eu queria saber, pois parece que você está formando médico só para a área de saúde no que diz respeito ao aspecto social, tirando o papel científico do médico. Entendi que as diretrizes estavam excluindo essa parte científica. Isso discordo muito; enfocar mais a parte clínica. Conheço vários médicos que se formaram e não foram clinicar, foram pesquisar e trabalham na Fiocruz. É muito importante.

estudante N-Promed - É uma das partes mais fundamentais, seja pesquisa científica de laboratório, seja pesquisa qualitativa. Estava estudando isso hoje e uma das coisas que eu estava lendo é que a maioria das melhoras de qualidade de vida durante o curso da história foi muito mais por essas pesquisas e a aplicação delas do que dar remédio para paciente, do que aquela intervenção do médico.

estudante N-Promed - Era o que estava com medo: de tirar toda essa capacidade do médico de ser cientista e jogar para o biólogo, para o biomédico.
\end{abstract}

Confirmando a clareza dos estudantes sobre suas expectativas em relação à formação para a sociedade atual, o depoimento do estudante N-Promed sobre a avaliação feita na disciplina Mecanismos Básicos do Adoecimento (MBA) sugere, inclusive, inovação curricular que esbarra em questões administrativas e acadêmicas históricas não só no ensino médico, mas no superior de modo geral.

"A disciplina é sucesso dentro da turma; a turma gosta muito porque começamos a estudar medicina. Algumas propostas foram colocadas; uma delas é que, já que vemos icterícia na MBA, será que não seria interessante ficarmos no hospital ou no posto de saúde? Aumenta um pouco a carga curricular dela (...) Temos, por exemplo, acidose. Então vamos à UTI ver como funciona. Não é separar a prática da teórica. Vamos tentar fazer que a MBA tenha essa parte prática também. Começamos a conversar sobre isso e percebemos que não temos horário para isso. Como vai ser?! Vai aumentar a carga horária ou será que temos que pensar em podar o que está em excesso? Sou monitor de Biologia Celular e dentro da disciplina já se chegou a um consenso de que medicina tem uma carga horária muito grande em Biologia Celular. Temos horários de aula sobrando em Biologia Celular. É conclusão até do Departamento de Biologia Celular, só que a faculdade não tem contato com a Biologia Celular, são departamentos diferentes e não consegue haver a troca, não consegue haver a comunicação. Às vezes a universidade pública tem pouca mobilidade, e muita burocracia. Vamos ver o que acontece (...). Colocam profes- 
sores para dar aula e tentar explicar o que eles aprendem na fisiopatologia, os sinais e sintomas. Na verdade, nada se transformou, a essência do currículo, infelizmente, continua a mesma. Como você aprende a MBA? Sentada, sala de aula, professor, só que, ao invés do retroprojetor, tem o datashow" (estudante N-Promed).

O que chama a atenção é a maneira com a qual os estudantes lidam com as tentativas de inovação curricular, considerando vários fatores, entre os quais os que, parecendo desafios intransponíveis, transformam-se em incentivo para a melhoria das condições da sua formação, matéria de críticas consistentes e concepções com vieses transformadores.

\begin{abstract}
“Na minha opinião, não que nós tenhamos um grande poder ou conhecimento. A medicina integral, de certa forma, fez certo sucesso, porque está dentro de uma lógica de mundo: todo mundo vê um problema, chega no hospital e é verdade. O paciente pergunta ao médico que doença ele tem; ele não pensa que tem uma doença no coração e por isso deve ir ao cardiologista. Os alunos sabem que existe esse problema, mas quando tentamos conversar, existem diversas opiniões. Mas o problema que precisa ser mudado é que as coisas não acontecem. Mesmo que não haja unanimidade, se a gente puser no papel, se a gente tiver a capacidade de trazer à tona a discussão, acho que a gente consegue avançar um pouco. Vamos tirar o estudante do mundo dele, em que a lógica é estudar para passar na prova. Participar de uma reunião de reforma curricular representa perder tempo, por exemplo, de monitoria que não conta para o $\mathrm{CR}$. O aluno diz: 'vou ter que estudar para passar na prova. Se eu perder tempo com a reunião de reforma curricular, eu vou perder a monitoria'" (estudante N-Promed).
\end{abstract}

Acresce-se a esse potencial crítico uma necessidade de abertura ao diálogo com a experiência ou, mais especificamente, com professores que orientem e que se disponham a também abrir-se para o diálogo. Persiste, na formação de nível superior, uma relação de poder que caracteriza, segundo Habermas (1994), uma ação instrumental. Para Habermas há várias formas de coordenar a ação social, usualmente estabelecidas, mas nem todas produzindo o efeito de levar os agentes a um consenso verdadeiro e à interação: a ação teleológica, ou dirigida a fins, na qual os atores se instrumentalizam reciprocamente para atingir os fins planejados para os seus êxitos individuais. Seria, portanto, uma ação instrumental, utilitarista, na qual planos individuais se coordenam apenas para obter sucessos também individuais e que produz interação até o limite em que se equilibram os interesses; a ação estratégica, também dirigida ao êxito, mas que amplia o conceito de ação teleológica no sentido de que há uma intenção de um dos participantes de influenciar o outro nas tomadas de decisão para um acordo. Entram nesse contexto não só elementos do mundo objetivo, como também do mundo subjetivo e a linguagem, 
apenas como um meio de provocar efeitos perlocucionários, ou seja, de convencer o outro por meio de expressões significativas e a ação voltada (ou orientada) ao entendimento, dirigida por processos de entendimento, nos quais "os participantes realizam seus planos em situação de ação definida em comum, segundo um acordo recíproco" (Habermas, 1994, p. 493).

\begin{abstract}
“Não que o estudante não tenha potencial para fazer isso [mudança na formação médica vigente], mas é que até agora ele não parou para prestar atenção nisso; em nenhum momento eles tiveram a chance de parar (...) ou eles vêm de um colégio público bom, Pedro II ou CAP, ou vêm de um colégio particular. Então, vai ter toda um cultura a ser transformada. Você entra para a universidade, para a medicina, com a cabeça já formada. Você não tem, em nenhum momento da faculdade, oportunidade de discutir a formação" (estudante N-Promed).
\end{abstract}

Apesar de não contar com o auxílio do Promed, a escola investigada tem feito inúmeras tentativas de inovação curricular. Entretanto, o próprio corpo docente e os estudantes fazem críticas, cada um a seu modo, à forma como são conduzidas, sem um projeto pedagógico claro. Ao mesmo tempo, é unânime a afirmativa de que algo novo está acontecendo, embora em pequena escala.

Para os estudantes, há professores que "tiram os estudantes da cadeira para mostrar coisas além e fazem algo mais do que as longas exposições orais"; insistem na necessidade de se investir no professor; têm clareza sobre a necessidade de se formar especialistas e de se criarem 'áreas verdes' de modo que haja opção para os estudantes procurarem atividades de seu interesse; consideram que a criação da disciplina medicina integral, apesar do sucesso, é uma medida paliativa, uma vez que não contamina as outras disciplinas, dispersando seus objetivos de ser 'ponte' exemplar entre teoria e prática. Ilustram esta consciência dos estudantes as falas seguintes:

“O conhecimento científico foi aumentando e daí você tem que ser mais especialista, e hoje as pessoas pararam para pensar: qual é o impacto disso na sociedade? Foram abrindo várias vagas para residência sem fazer uma pesquisa de quantos especialistas de cada área tem que ter em cada região do Brasil; foram abrindo principalmente no Sul e Sudeste e aí as pessoas iam se formando" (estudante N-Promed).

\footnotetext{
“Sabe por que Medicina Integral é considerada paliativa? Porque você vê um avanço social em medicina integral e vai passar todo o resto de sua vida aqui nesse hospital vendo Lúpus. O que mais vi até agora foi Lúpus (...) achava que era endêmico! Você aprende algumas coisas aqui que são importantes de você aprender; é o local que você vai aprender e quando você vir na realidade, poder enca-
} 
minhar para um centro de referência. Mas e as outras coisas? Vão se perder porque você só viu isso no início da faculdade" (estudante N-Promed).

“Quero voltar a falar da questão do 'cotoquinho do cotoquinho'. Se você forçar isso demais, você tirar o 'cotoquinho do cotoquinho', a universidade vai perder o seu sentido, pois quem é a universidade? A universidade está lá para ensinar a Ciência - não na sua forma só prática, mas também na sua forma teórica. Porque, se tirar toda a parte teórica, vai virar parte técnica. A universidade não é mais centro de aprendizagem (...) é centro de excelência. Outro dia estava pensando: por que é universidade? Por que não existe um curso técnico de medicina? Já me perguntei por que estou estudando essa porcaria de biologia celular, de bioquímica (...) Mas tudo tem sua lógica. É óbvio que tenho que aprender bioquímica" (estudante N-Promed).

Com uma visão um tanto mais romântica, mas verdadeira no sentido de que revela os desejos de uma formação mais integral e humanizada, os estudantes da Escola Promed constatam que há “a deturpação do que se está ensinando, pois nós temos uma escola que profissionaliza e nós queríamos uma escola onde nós fôssemos formados, que fosse mais ativa, que fosse construtora do conhecimento". Sem qualquer conotação conservadora caracterizam alguns professores como "impecáveis, (...) aqueles que viram os nossos ídolos, dão as mesmas aulas às vezes, mas que são nota 10. Por exemplo, alguns professores que são especialistas, mas tem a visão geral da medicina".

Apesar de toda adversidade que apontam, correspondente aos impedimentos para efetivas inovações curriculares, o otimismo vence o pessimismo quando um estudante se pronuncia.

“Não vai ser a virologia que vai desanimar, não vai ser a neuroanatomia que vai desanimar, não vai ser nada disso. Estar com a sensação de daqui a algum tempo, quando eu for receber meu diploma, nós não estaremos saindo, que eu estou dando continuidade àquilo que comecei, é isso que é uma proposta da educação continuada, a humanização nos termos das diretrizes curriculares. Às vezes me pergunto: para que mudar? Será que aquele formado com novo currículo será melhor médico que o antigo? Uma das respostas para essas minhas indagações é porque mudou a estrutura do sistema de saúde. Então, discutir o perfil do médico é discutir o perfil do médico para essa estrutura nova na qual eu acredito" (estudante Promed).

Insistindo na firmeza com que os estudantes se referem à sua formação, para nós ficou a certeza de que, mais do que nunca, o modelo curricular e os métodos de ensino que aí estão não seduzem mais. Falta, a nosso ver, dar sentido àquilo que se ensina, problematizar as questões do cotidiano, con- 
vencermo-nos de que não sabemos tudo o que ensinamos, pois a velocidade do conhecimento extrapola nossa capacidade de absorvê-lo no mesmo ritmo. Mais importante do que as aulas que preparamos é colocar os estudantes em permanente estado de dúvida, de desconfiança das verdades absolutas, um processo de difícil percurso, mas essencial se quisermos legar às novas gerações profissionais competentes.

\section{Considerações finais}

A pesquisa vem apontando que, para um efetivo movimento de transformação no ensino médico, há de se transformar as práticas de saúde hegemônicas que hoje legitimam as concepções tradicionais, ainda evidenciadas em algumas falas dos sujeitos da pesquisa e que se reproduzem no âmbito das disciplinas. A legitimidade destes saberes só será tensionada quando for reconhecido o valor de novas práticas de cuidado em saúde que, por sua vez, induzem à construção de novos objetos do conhecimento.

Nessa interlocução de saberes - propiciada pela articulação da academia e dos serviços de saúde, por meio de um novo contrato social da universidade, por um lado, e, por outro, pela estruturação curricular orientada pela integração educação-trabalho - será possível avançar em projetos inovadores.

Mesmo que a ruptura de resistências seja um longo processo, de avanços e recuos, as DCN instalaram novas concepções de saúde e de educação, capitaneadas por novas políticas nestes campos e evidenciadas em iniciativas que articulam o individual com o coletivo, democratizam as relações entre professores e estudantes, incluem outras vozes nas decisões pedagógicas e admitem a parceria - tanto no campo do saber quanto no institucional para definir novos rumos para a formação profissional.

Não é casual que muitas falas, tanto dos professores quanto dos estudantes, se não identificadas por Promed ou N-Promed, em muitos pontos se assemelham. É indubitável a desconfiança de que algo não vai bem no ensino médico. Há insatisfação por parte dos estudantes, dos professores e dos usuários dos serviços. O que faz a diferença neste estudo é a vantagem do recurso Promed que facilita a 'saída dos muros', equipa a escola, promove a pesquisa envolvendo estudante e pessoal dos serviços simbolicamente remunerados, entre outras ações. Por outro lado, na escola N-Promed a desconfiança não encontra eco, não é estimulada para superar-se pela absoluta falta de recurso. Se medido fosse, em números, o nível de empenho dos professores, e especialmente dos estudantes, para realizar inovações, é possível que as escolas atinjam níveis bem próximos.

O necessário encontro de inovações curriculares no ensino médico com as políticas públicas no campo da saúde, em fase de implantação e, em al- 
guns casos, de implementação, cria oportunidades que, com esforço e compromisso dos profissionais das duas áreas, em médio e longo prazo certamente plantarão a semente da transformação. Espera-se que o cumprimento dos princípios da Reforma Sanitária e a melhoria da qualidade no atendimento do SUS sejam beneficiários desta transformação, refletindo-se no cuidado e na promoção da saúde do povo brasileiro.

\section{Notas}

1 Professora Adjunta do Núcleo de Tecnologia Educacional para a Saúde da Universidade Federal do Rio de Janeiro (Nutes/UFRJ) e coordenadora do Laboratório de Currículo e Ensino do Nutes. Doutora em Educação pela UFRJ. < victoria@nutes.ufrj.br>

2 Este artigo é produto de um projeto de investigação com apoio do CNPq (2003-2008).

3 As Diretrizes Curriculares Nacionais para o Ensino Médico foram homologadas pelo MEC, por meio do Parecer CNE/CES n. 1.133/2001, Resolução CNE/CES n. 4, de 7 de novembro de 2001 .

4 Brant e Silveira (2004, p. 97) definem essa expressão como um processo no qual “ensino e aprendizagem, passos dialéticos e inseparáveis, solidariamente relacionados se fundem, gerando um processo único em permanente movimento e caracteriza uma ação que Bleger (1998, p. 59) denominou de ensinagem".

5 Grupo focal é uma técnica qualitativa utilizada com pequenos grupos de pessoas reunidas para aprofundar e/ou avaliar conceitos, identificar problemas, constituindo-se em uma ferramenta que substitui, com vantagem, as entrevistas, pois a palavra é livre de coação e o debate com outros participantes enriquece o tema em discussão.

6 Neste texto, as duas escolas investigadas são nomeadas por Escola Promed e Escola N-Promed; os estudantes são indicados por estudante Promed e estudante N-Promed; e os professores, por professor Promed e professor N-Promed.

7 A Aprendizagem Baseada em Problemas (ABP) é um método de ensinagem, centrado no aluno, desenvolvido em pequenos grupos tutoriais. Apresenta problemas em contexto clínico, sendo um processo ativo, cooperativo, integrado e interdisciplinar. Os estudos acerca da metodologia da ABP têm se enriquecido com os conhecimentos sobre a gênese do processo cognitivo, da aprendizagem do adulto e da fisiologia da memória, ressaltando-se a importância da experiência prévia e da participação ativa como pontos fundamentais para a motivação e aquisição de conhecimentos. 
8 “Portfolio é uma sistemática e organizada 'colecção' de evidências (trabalhos) usados pelo professor e pelos alunos para monitorizar o desenvolvimento dos conhecimentos, competências e atitudes dos estudantes (...), onde não faltam as análises e reflexões sobre as suas aprendizagens. Não será exagero afirmar que o currículo, a instrução e a avaliação se interceptam no portfolio" (Nunes, 1999).

9 Trata-se de estabelecer conexões entre as possíveis atividades que se ofereçam em um currículo e o contexto de uma situação ideal de fala, objetivando a formação de competência argumentativa e da conseqüente tomada de consciência, por parte dos professores e alunos, de que correm o risco de terem sempre postos em questão os argumentos dos seus discursos. Sem dúvida, formar vontades e opiniões que sejam reciprocamente acordadas, por meio de situações ideais de fala, com base em ações orientadas ao entendimento, pode ser um meio de formar o sujeito autônomo e competente.

10 Os dados da pesquisa confirmam essa tendência. Dos estudantes do $1^{\circ}$ ano, com apenas três meses de freqüência à escola, 24,2\% já optaram por alguma especialidade. Esse índice aumenta significativamente entre os estudantes do $3^{\circ}$ ano $(41 \%)$ e do $5^{\circ}$ ano $(62,7 \%)$, que já se encontram em ambiente hospitalar e, portanto, vivendo experiências com doentes, embora ainda não tenham cursado todas as disciplinas que compõem a proposta de formação integral. Destaca-se o expressivo aumento do índice de escolha da especialidade antes da entrada na escola médica. Dos 79,6\% dos egressos atuantes em alguma especialidade, 20,5\% fizeram esta opção antes de entrarem na escola. Destes, 46,4\% fizeram esta escolha antes de ingressarem na graduação. Ver Cabral e Brant (2004).

\section{Referências}

ALMEIDA, Marcio José. 1999. Educação médica e saúde: possibilidades de mudança. Londrina-Rio de Janeiro: Abem/UEL.

BALZAN, Newton César. 2003. Inovação/ visão única. Interface: Comunicação, Saúde, Educação, v. 7, n. 13, p. 149-158.

BLEGER, José. 1998. Temas de psicologia: entrevista e grupos. São Paulo: Martins Fontes.

BRANT, Victoria; SILVEIRA, Lia. 2004. Grupo de adesão ao tratamento: espaço de "ensinagem" para profissionais de saúde e pacientes. Interface: Comunicação, Saúde, Educação, v. 9, n. 16, p. 91-104.

BRASIL. 1988. Constituição da República Federativa do Brasil.

BRASIL. 1990. Lei Orgânica da Saúde $n^{\circ}$ 8.080, de 19 de setembro de 1990.
CABRAL, Wilson; BRANT, Victoria. 2004. A escolha precoce da especialidade pelo estudante de medicina: um desafio para a educação médica. Revista Abem, v. 28, n. 2, p. 133-144.

CUNHA, Maria Isabel. 2003. Inovações pedagógicas: tempos de silêncios e possibilidades de produção. Interface: Comunicação, Saúde, Educação, v. 7, n.13, p.149-158.

DICCIONARIO de las ciências de la educación. 1988. Madri: Santillana.

FERREIRA, José Roberto. 1988. Educación médica en el contexto del desarrollo socioeconómico y de salud. Washington. (Mimeo).

FEUERWERKER, Laura C. M. 2002. Além do discurso de mudança na educação mé- 
dica: processos e resultados. São PauloLondrina-Rio de Janeiro: Abem/Hucitec/Rede Unida.

FREIRE, Paulo; SHOR, Ira. 1986. Medo e ousadia: o cotidiano do professor. São Paulo: Paz e Terra.

GONZALEZ, Maria Tereza; MUÑOZ, Juan Manuel E. 1987. Innovación educativa: teorías y procesos de desarrollo. Barcelona: Humanitas.

HABERMAS, Jürgen. 1994. Teoría de la acción comunicativa: complementos y estudios previos. Madrid: Catedra.

HUBERMAN, Michaël. 1973. Como se realizan los cambios en la educación: una contribución al estudio de la innovación. Paris: Unesco.

JORGE, Leila. 1996. Inovação curricular: além da mudança dos conteúdos. $3^{\mathrm{a}}$ ed. Piracicaba: Unimep.

LEITE, Denise. 2003. Inovação/tensão entre poderes e saberes... Interface: Comunicação, Saúde, Educação, v. 7, n. 13, p. 152-153.

LUCARELLI, Elisa. 2003. Innovación/esperanza. Interface: Comunicação, Saúde, Educação, v. 7, n. 13, p. 153-154.

MATUS, Carlos. 1993. Politica, planejamento e governo. Brasília: Ipea. (Série Ipea, 143).

MEC (Ministério da Educação). Resolução CNE/MEC n. 4, de 11 de novembro de 2001.

MEC/MS (Ministério da Educação/Ministério da Saúde). 2002. Programa de Incentivo às Mudanças Curriculares no Ensino Médico (Promed). Brasília: Secretaria de Políticas de Saúde, Ministério da Saúde/Secretaria de Educação Superior, Ministério da Educação.
MINAYO, Maria Cecília de S. 1998. O desafio do conhecimento: pesquisa qualitativa em saúde. $5^{\text {a }}$ ed. São Paulo-Rio de Janeiro: Abrasco/Hucitec.

NUNES, Ivônio B. 2001. Inovações na educação. Disponível em: <www.intelecto.net/ ead/inovacoes.htm>. Acesso em: 02 nov. 2004.

NUNES, Jorge. 1999. Portfolio: uma nova forma de encarar a avaliação? Disponível em: <www.iie.min-educ.pt/edicoes/ noe/index.htm $>$. Acesso em: 08 out. 2004.

POSTMAN, Neil. 1994. Tecnopólio: a rendição da cultura à tecnologia. São Paulo: Nobel.

ROVERE, Mario. 1993. Planificación estratégica de recursos humanos en salud. Serie Desarrollo de Recursos Humanos, n. 96. Washington: Organização Pan-Americana de Saúde, Organização Mundial da Saúde.

SANTOS, Boaventura S. 2002. A crítica da razão indolente: contra o desperdício da experiência. São Paulo: Cortez.

SAVIANI, Dermeval. 1980. A filosofia da educação e o problema da inovação em educação. In: GARCIA, Walter (org.). Inovação educacional no Brasil: problemas e perspectivas. São Paulo: Cortez, p. 1529.

SEBARROJA, Jaime C. 2002. El profesorado y la innovación educativa. In: LEÓN, Pedro C. (coord.). La innovación educativa. Andalucía: Ediciones Akal, p. 11-26.

Recebido em 05/11/2004

Aprovado em 17/12/2004 